University of New Hampshire

University of New Hampshire Scholars' Repository

$12-20-1997$

\title{
Distributions of beryllium 7 and lead 2109, and soluble aerosol- associated ionic species over the western Pacific: PEM West B, February-March 1994
}

Jack E. Dibb

University of New Hampshire, jack.dibb@unh.edu

R. Talbot

University of New Hampshire, robert.talbot@unh.edu

Barry Lefer

University of Houston - Main

Eric Scheuer

University of New Hampshire - Main Campus, Eric.Scheuer@unh.edu

G L. Gregory

NASA

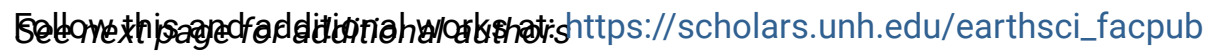

Part of the Atmospheric Sciences Commons

\section{Recommended Citation}

Dibb, J. E., R. W. Talbot, B. L. Lefer, E. Scheuer, G. L. Gregory, E. V. Browell, J. D. Bradshaw, S. T. Sandholm, and H. B. Singh (1997), Distributions of beryllium 7 and lead 2109, and soluble aerosol-associated ionic species over the western Pacific: PEM West B, February-March 1994, J. Geophys. Res., 102(D23), 28287-28302, doi:10.1029/96JD02981.

This Article is brought to you for free and open access by the Earth Sciences at University of New Hampshire Scholars' Repository. It has been accepted for inclusion in Earth Sciences Scholarship by an authorized administrator of University of New Hampshire Scholars' Repository. For more information, please contact Scholarly.Communication@unh.edu. 


\section{Authors}

Jack E. Dibb, R. Talbot, Barry Lefer, Eric Scheuer, G L. Gregory, E V. Browell, J D. Bradshaw, S T. Sandholm, and H B. Singh 


\title{
Distributions of beryllium 7 and lead 210, and soluble aerosol-associated ionic species over the western Pacific: PEM West B, February - March 1994
}

\author{
J. E. Dibb, ${ }^{1,2}$ R. W. Talbot, ${ }^{1,2}$ B. L. Lefer, ${ }^{1}$ E. Scheuer, ${ }^{1}$ G. L. Gregory, ${ }^{3}$ \\ E. V. Browell, ${ }^{3}$ J. D. Bradshaw, ${ }^{4}$ S. T. Sandholm, ${ }^{4}$ and H. B. Singh ${ }^{5}$
}

\begin{abstract}
Aerosol sampling for the determination of the concentrations of soluble ionic species and the natural radionuclides ${ }^{7} \mathrm{Be}$ and ${ }^{210} \mathrm{~Pb}$ was conducted from the NASA DC-8 over the western Pacific as part of GTE/PEM-West B during February - March 1994.

Concentrations of most soluble ionic species in the free troposphere were higher in samples collected on flights originating from Hong Kong and Japan than those collected further east over the open ocean. In both regions the measured concentrations were higher than those found during PEM-West A (fall 1991). Activities of ${ }^{210} \mathrm{~Pb}$, a tracer of air masses influenced by sources on the Asian continent, showed the same patterns. These data indicate the effect of stronger continental outflow from Asia over the western Pacific during the spring compared to fall season. For readily scavenged aerosol-associated species and soluble acidic gases the strongest indications of Asian outflow were restricted to altitudes below $6 \mathrm{~km}$. The distribution of the continental tracer ${ }^{210} \mathrm{~Pb}$ was also compared to those of a large number of gas phase species measured on the DC-8. Relatively strong correlations were found with $\mathrm{O}_{3}$ and peroxyacetylnitrate (PAN), but only during the flights over the remote Pacific. During PEMWest A, similar correlations were seen, but they were stronger near Asia. We believe that these correlations are a signature of continental air that has been processed by deep wet convection over land before being advected over the ocean. One flight over the Sea of Japan provided the opportunity to sample upper troposphere/lower stratosphere air in and around a tropopause fold. Concentrations of ${ }^{7} \mathrm{Be}$ reached $7 \mathrm{pCi} \mathrm{m}^{-3} \mathrm{STP}$, and peak $\mathrm{O}_{3}$ mixing ratios of $480 \mathrm{ppb}$ were encountered at $10.7 \mathrm{~km}$. The ${ }^{7} \mathrm{Be}$ data are used to estimate the fraction of stratospheric air mixed down into the troposphere by circulation in the fold.
\end{abstract}

\section{Introduction}

The NASA DC-8 flew 16 flights over the western Pacific during February-March 1994. The Global Tropospheric Experiment/Pacific Exploratory Mission-West B (GTE/PEM-West B) mission was designed to allow characterization of the influence of continental outflow from Asia on the composition of free tropospheric air over the ocean. In particular, PEM-West B was intended to complement the PEM-West A mission, which was flown in the same region in September - October 1991, thus allowing comparison between the spring (much outflow expected) and fall seasons (when outflow events are less common) [e.g., Prospero et al., 1985; Merrill et al., 1989] (see also the special issue of the Journal of Geophysical Research on PEM-West A, volume 101 (D1), 1996). Descriptions of the GTE instrumentation on board the DC-8, and the specific scientific objectives of each flight, are given by Hoell et al. [this issue].

\footnotetext{
'Institute for the Study of Earth, Oceans and Space, University of New Hampshire, Durham.

${ }^{2}$ Department of Earth Sciences, University of New Hampshire, Durham. ${ }^{3}$ NASA Langley Research Center, Hampton Virginia.

${ }^{4} \mathrm{School}$ of Earth and Atmospheric Sciences, Georgia Institute of Technology, Atlanta.

5NASA Ames Research Center, Moffet Field, California.
}

Copyright 1997 by the American Geophysical Union.

Paper number 96JD02981.

0148-0227/97/96JD-02981\$09.00
This paper focuses on the spatial and vertical distributions of the natural radionuclide tracers ${ }^{7} \mathrm{Be}$ and ${ }^{210} \mathrm{~Pb}$. Beryllium 7 can provide information about stratospheric influence on the composition of tropospheric air, while ${ }^{210} \mathrm{~Pb}$ is considered to be an indicator of air masses that have been influenced by ${ }^{222} \mathrm{Rn}$ emissions over continental regions. The distributions of these tracers are compared to those of aerosol-associated soluble ionic species and several gas phase species measured from the DC-8 during PEM-West B. Comparisons are also made to the corresponding distributions observed during PEM-West $\mathrm{A}$.

\section{Methods}

The aerosol sampling systems (identical probes operated in parallel for the collection of radionuclide and ionic species samples) and analytical techniques were unchanged from PEM-West $\mathrm{A}$ [Dibb et al., 1996]. As during PEM-West A, aerosol collection was restricted to flight legs at constant altitude. Sample integration time was reduced to $20-30 \mathrm{~min}$ for all flights, resulting in the collection of 140 sample pairs. Improved sensitivity of the custom ion chromatographs used on board the DC-8 during PEM-West B resulted in comparable, or lower, detection limits for all ionic species relative to our results for PEM-West A, despite the smaller sample volumes. Detection limits are dominated by variability in the loadings on "blank" filters and are inversely related to the volume of air filtered. For the mean sample volume during PEMWest B our detection limits were approximately $0.5 \mathrm{fCi}^{210} \mathrm{~Pb} \mathrm{~m}^{-3}$ STP, $15 \mathrm{fCi}^{7} \mathrm{Be} \mathrm{m}^{-3} \mathrm{STP}, 30$ parts per trillion by volume (pptv) $\mathrm{Cl}^{-}$, 
ำชัต

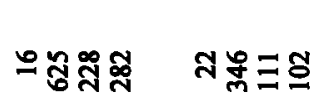

สะปร

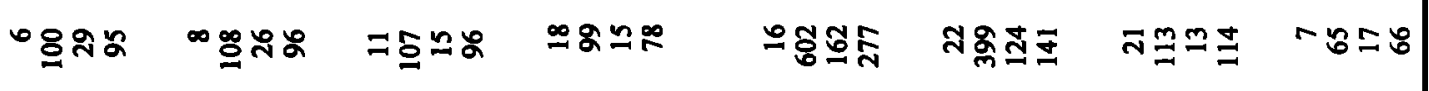

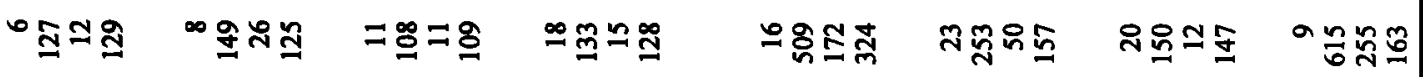

$0^{n}$

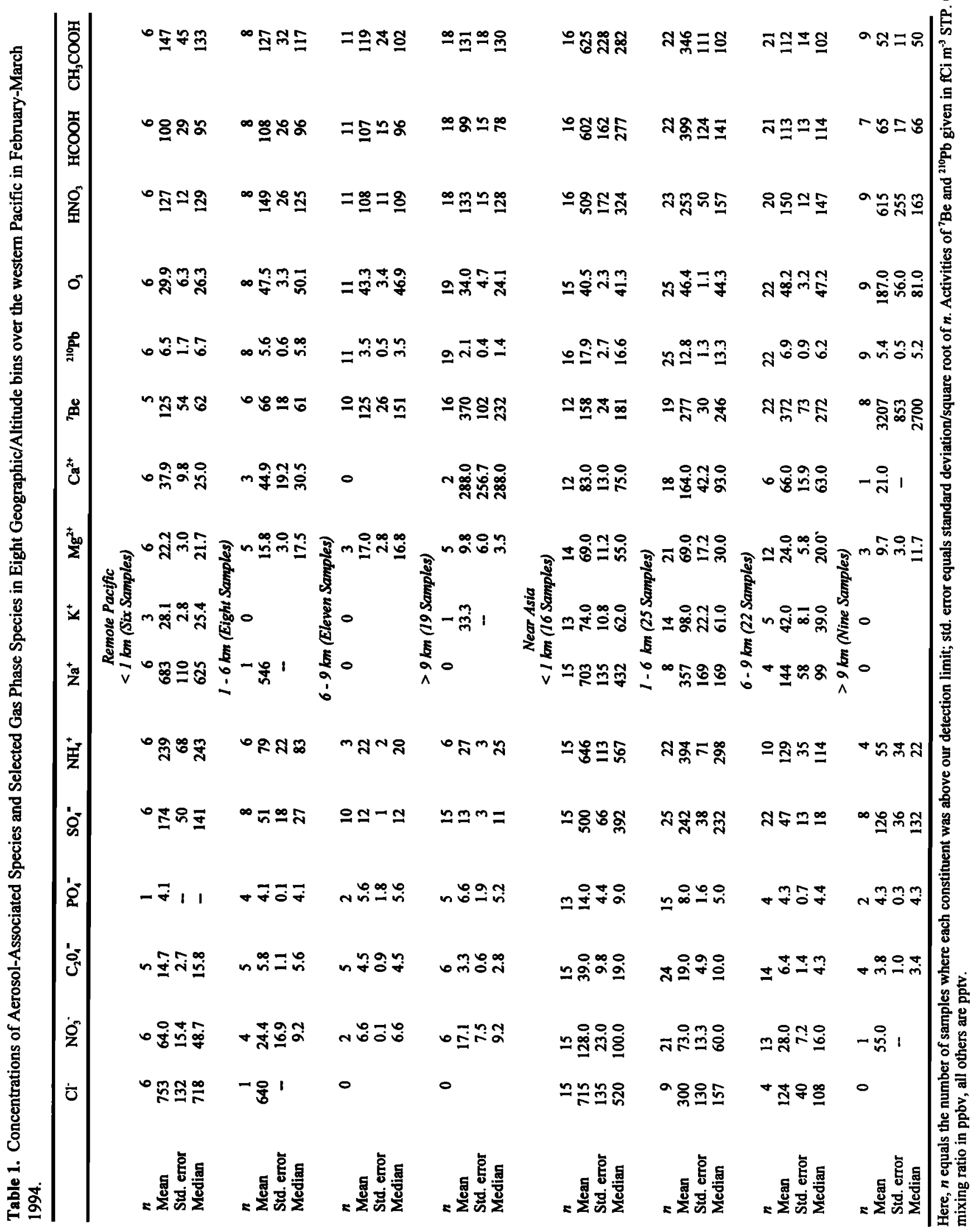



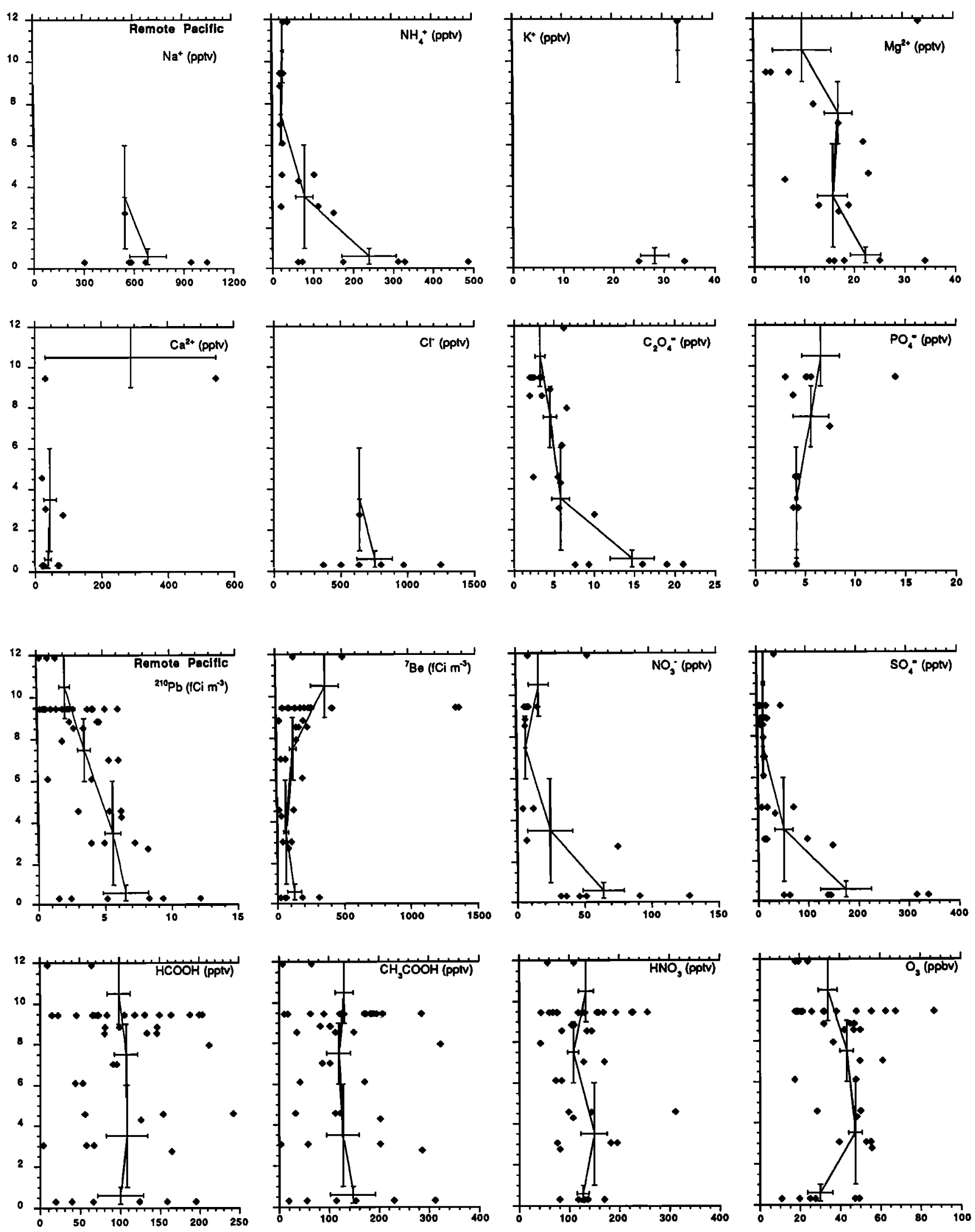

Figure 1. Mean concentrations of soluble aerosol-associated species, soluble acidic gases and ozone versus altitude (km) over the western Pacific during PEM-West B. All samples with concentrations above detection limits in the "remote Pacific" and "near-Asia" regions are plotted. The horizontal arms of the crosses represent the standard error of the mean for each species in the eight region/altitude bins presented in Table 1 , while the altitude range is encompassed by the vertical arms. 

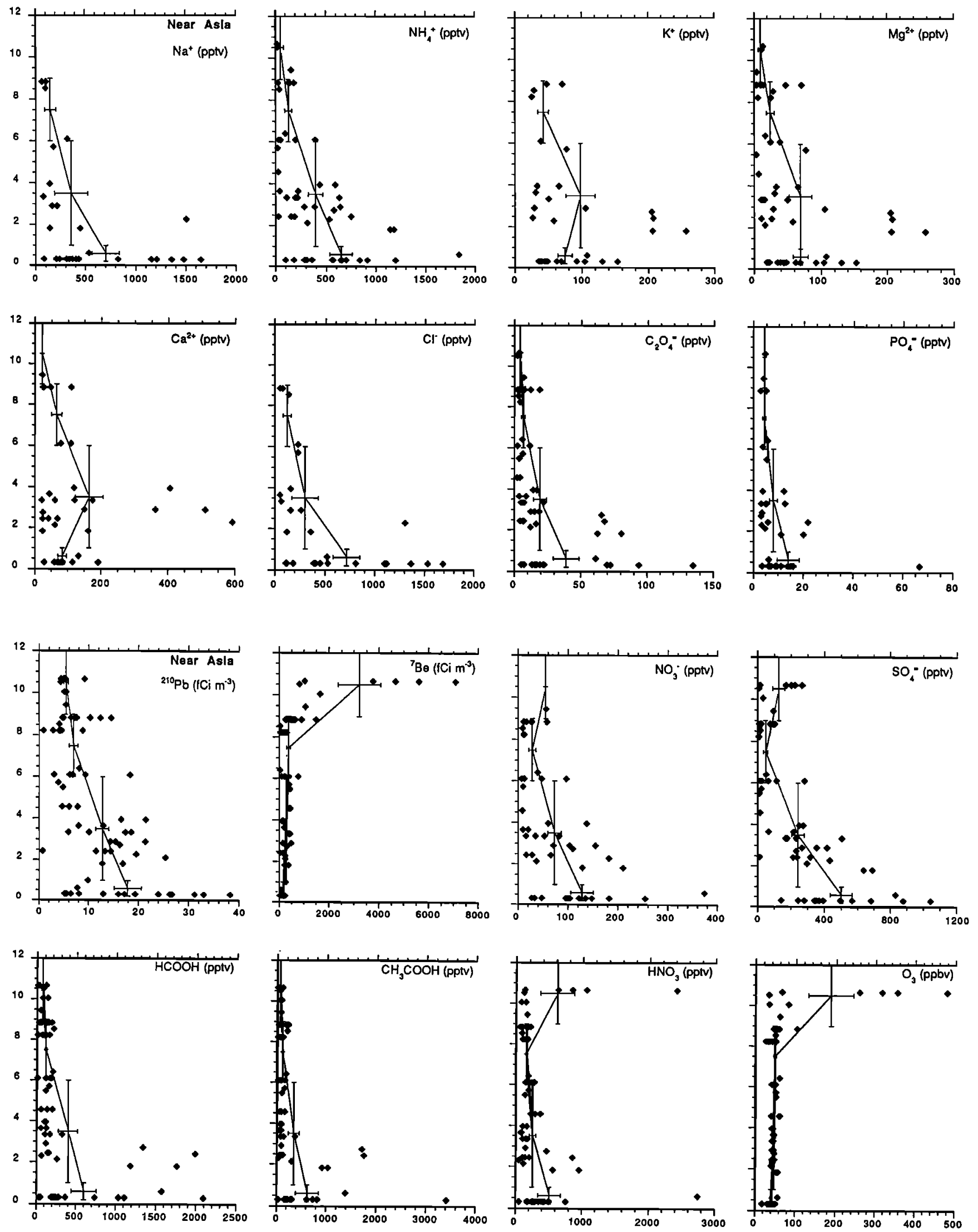

Figure 1. (continued) 

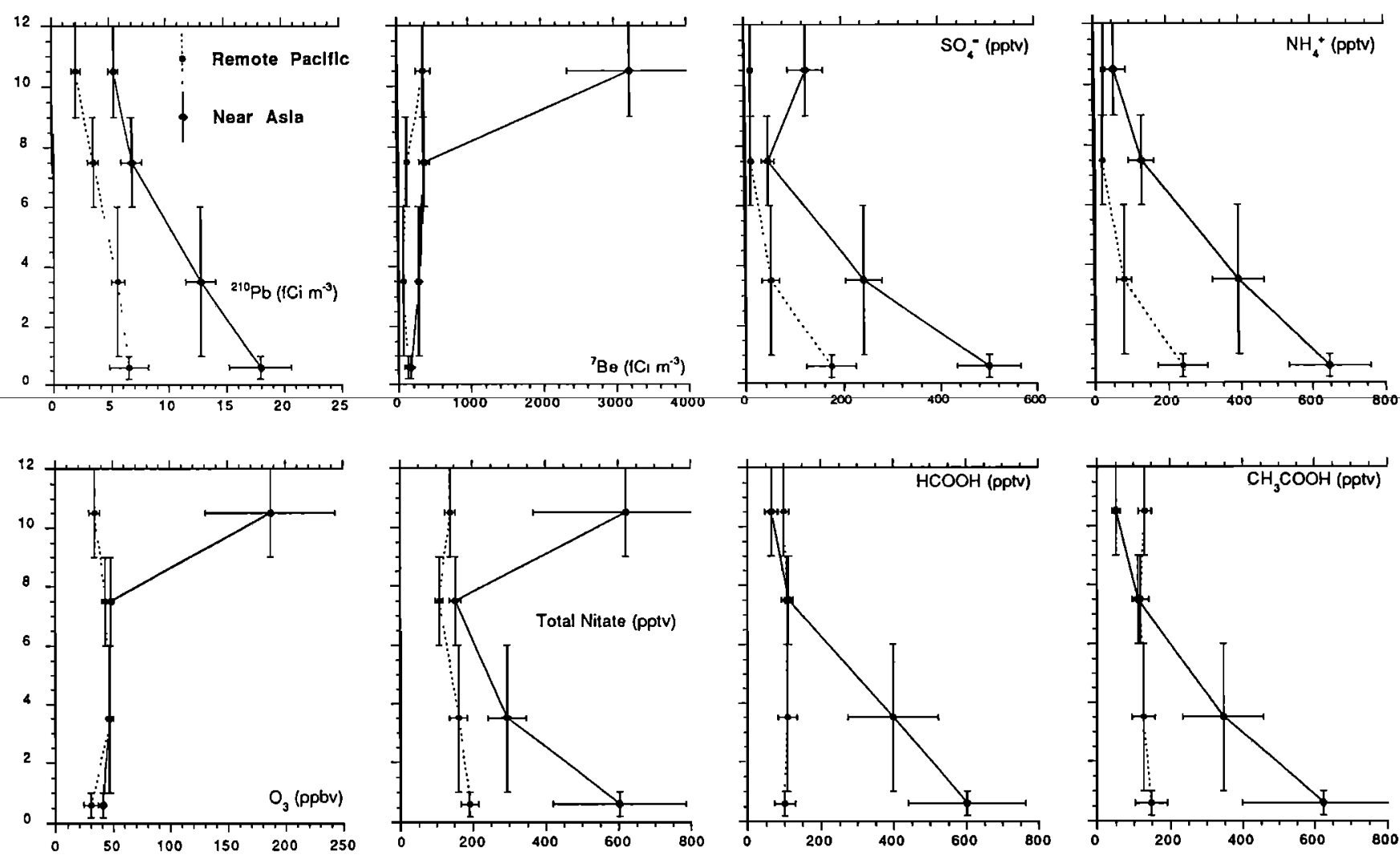

Figure 2. Comparison between the mean concentrations of selected species (those quantified in the most samples) in the two geographic regions. The crosses have the same meaning as in Figure 1.

4 pptv $\mathrm{NO}_{3}^{-}, 4$ pptv $\mathrm{SO}_{4}=2$ pptv $\mathrm{C}_{2} \mathrm{O}_{4}, 40$ pptv Na, 20 pptv $\mathrm{NH}_{4}^{+}$, 20 pptv $\mathrm{K}^{+}, 3$ pptv $\mathrm{Mg}^{2+}$, and $14 \mathrm{pptv} \mathrm{Ca}^{+}$. We use pptv concentration units $\left(\mathrm{mol}^{-12} \text { of analyte (mol of sampled air) }\right)^{-1}$ ) for aerosolassociated species to facilitate comparison to all of the gas phase measurements made concurrently on the DC-8.

The sample integration times on board the DC-8 for all other species discussed herein are shorter than those for the collection of aerosols (see companion papers in this issue for details of other measurements). A merged data set, where all other measurements were averaged over the collection time of each aerosol sample, was produced at the Georgia Institute of Technology. This merged product is used exclusively in this paper. The complete PEM-West $B$ data set and several different merged products are available through the Langley Distributed Active Archive Center.

\section{Results}

Following the lead of Dibb et al. [1996], we separate the PEMWest B aerosol samples into "remote Pacific" and "near Asia" regional groups. The first group includes 44 samples collected on flights 5 through the first half of flight 10 (Guam to Hong Kong), and the near Asia subset includes 72 samples from the end of flight 10 through flight 17 . An additional 24 samples were collected during the transit flights from Califomia to Hawaii (flight 4), Japan to Alaska (flight 18), and Alaska to California (flight 19). These samples were predominantly collected at cruise altitiudes $(>8 \mathrm{~km})$ and are not discussed herein, but are included in the archived data set.

Further division of the data set into altitude bins considers the marine boundary layer $(<1 \mathrm{~km})$ and three free tropospheric intervals (Table 1). An attempt was made to select the free tropo- spheric bin altitude intervals so that they contained nearly equal numbers of samples when both regions are considered. However, proportionally more time was spent at the highest altitudes in the remote region than near Asia. Table 1 also summarizes the concentrations of soluble acidic gases and $\mathrm{O}_{3}$, averaged over the integration time of each pair of aerosol samples. All samples with concentrations above our detection limits are plotted against altitude in Figure 1. It is apparent that data coverage is sparse (concentrations often near or below detection limits) in the free troposphere, particularly over the remote Pacific, for most aerosolassociated species except ${ }^{210} \mathrm{~Pb}(100 \%$ of samples above detection limit), $\mathrm{SO}_{4}{ }^{=}\left(94 \%>\right.$ detection limit), and ${ }^{7} \mathrm{Be}(84 \%>$ detection limit) (Table 1). However, near Asia, all of the soluble ionic species except $\mathrm{Na}^{+}$and $\mathrm{Cl}^{-}$were readily quantified in most (60-100\%) of the samples collected between 1 and $6 \mathrm{~km}$, with the low end of the range dropping to $18 \%\left(\mathrm{PO}_{4}{ }^{*}\right)$ for the 22 samples collected in the 6 - $9 \mathrm{~km}$ altitude bin (Figure 1, Table 1). In contrast, during PEMWest $\mathrm{A}, \mathrm{NO}_{3}{ }^{-}, \mathrm{SO}_{4}{ }^{-}$and $\mathrm{NH}_{4}{ }^{+}$were the only soluble ionic species we were able to quantify in any samples collected above $2 \mathrm{~km}$ altitude [Dibb et al., 1996]. In this light, even the low concentrations measured in the free troposphere over the remote Pacific suggest enhanced concentrations of soluble aerosol-associated species over much of the western Pacific in early spring relative to fall.

\section{Discussion}

\section{Comparisons Between Remote Pacific and Near Asia Regions}

Continental Influence. Concentrations of ${ }^{210} \mathrm{~Pb}$ range from 2.0 to 2.7 times higher in all altitude bins near Asia, but a steady decrease with altitude is apparent in both regions (Figure 2). Below 

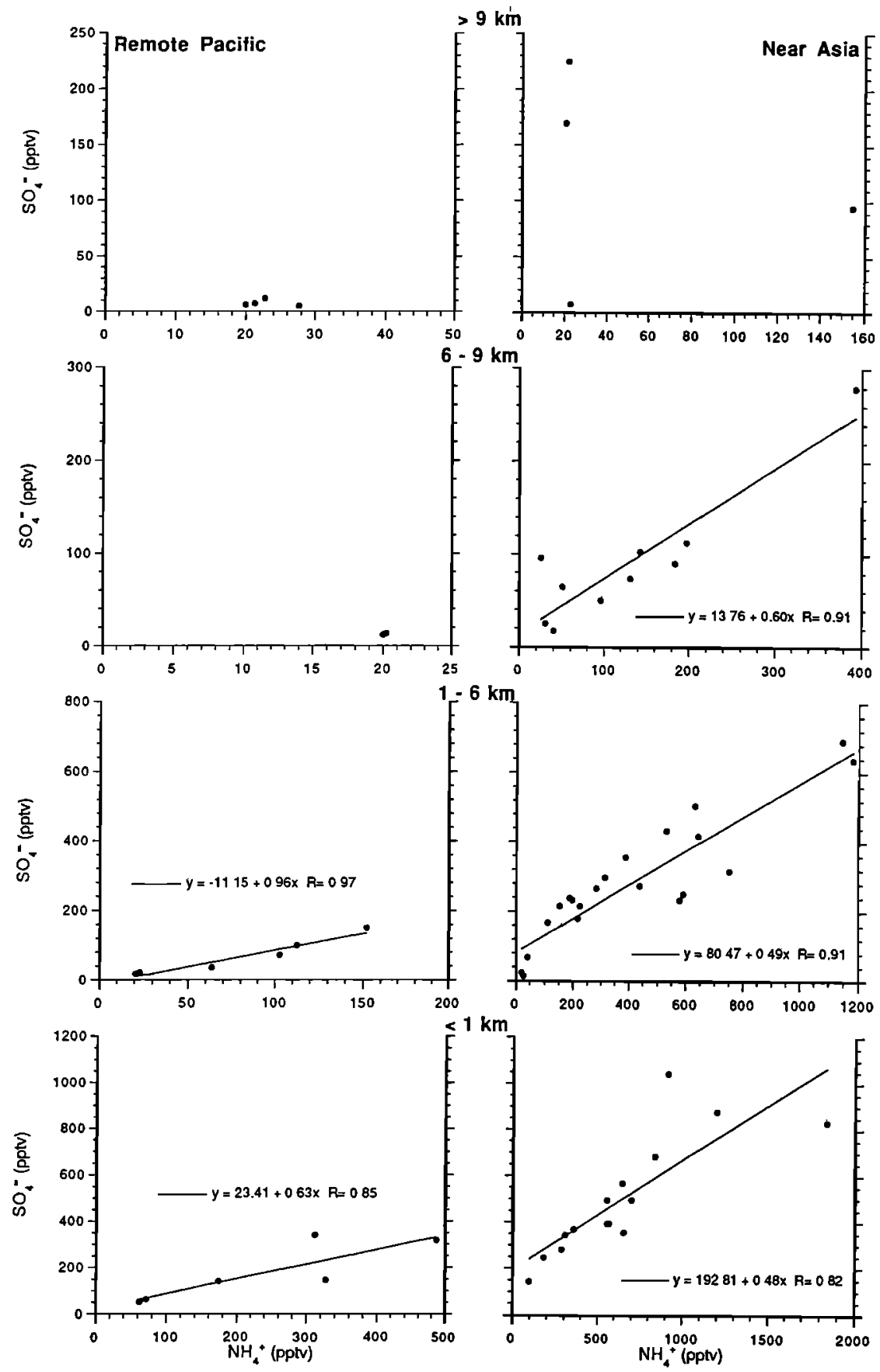

Figure 3. Scatterplots of $\mathrm{SO}_{4}{ }^{=}$versus $\mathrm{NH}_{4}{ }^{+}$in the eight data bins. Correlation coefficients for all bins without regression lines plotted (and more than three sample pairs) were $\leq 0.25$.

$9 \mathrm{~km}$ the trends in $\mathrm{SO}_{4}{ }^{=}$and $\mathrm{NH}_{4}{ }^{+}$concentrations are similar, but the near Asia region has mean concentrations that are 2.7- to 5.9-fold higher than those over the remote Pacific, with the largest differences in the two lowest altitude bins $(0-6 \mathrm{~km})$ (Figure 2). Sulfate tends to be nearly completely neutralized by $\left.\mathrm{NH}_{4}^{+}\left(\mathrm{NH}_{4}\right)_{2} \mathrm{SO}_{4}\right)$ near Asia while $\mathrm{NH}_{4} \mathrm{HSO}_{4}$ appears to be more prevalent further east, particularly in the 1-6 km bin (Figure 3). These profiles suggest that strong Asian sources of $\mathrm{SO}_{4}{ }^{-}$and particularly $\mathrm{NH}_{4}{ }^{+}$are impacting air masses advecting over the Pacific. Comparisons between air masses stratified into continental versus marine on the basis of back trajectory analyses reinforce this hypothesis [Talbot et al., this issue (a)]. Recent results from several flights southward from Tokyo during the summer season also suggest nearly complete neutralization of $\mathrm{SO}_{4}{ }^{-}$by $\mathrm{NH}_{4}{ }^{+}$close to land [Yamato and Tanaka, 1994]. However, these same flights found $\mathrm{H}_{2} \mathrm{SO}_{4}$ to be the dominant form of sulfate aerosol at latitudes below $30^{\circ} \mathrm{S}$, or more than $1000 \mathrm{~km}$ from land, while our winter samples even further from Asia contained significant amounts of $\mathrm{NH}_{4}^{+}$(Figure 3).

The concentrations of formic, acetic, and nitric acids decrease rapidly from the boundary layer up to $9 \mathrm{~km}$ near Asia, while no altitude gradients were found for any of these acids in the more remote region (Figure 2). Again, differences between the two 

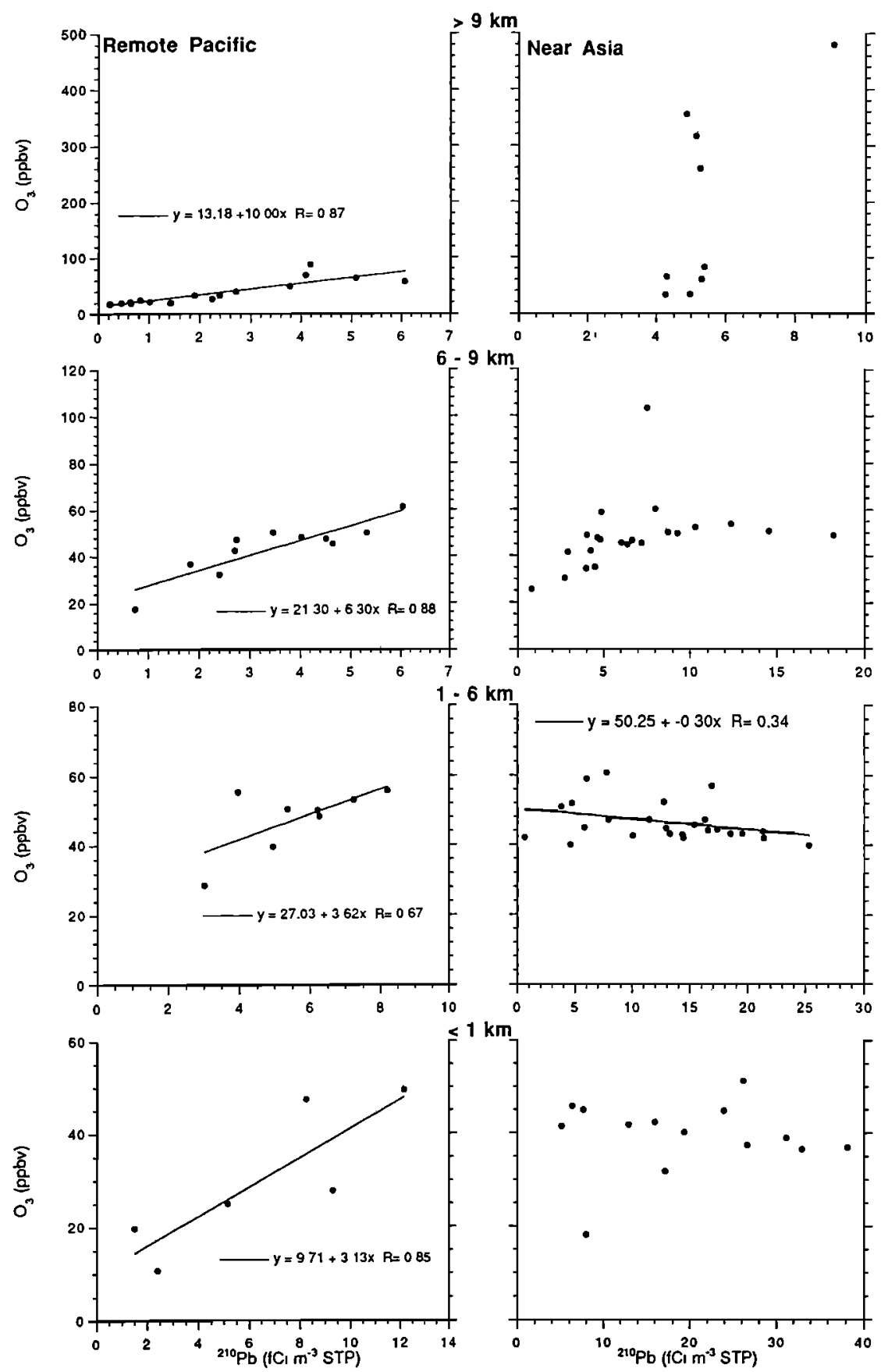

Figure 4. Scatterplots of ${ }^{210} \mathrm{~Pb}$ versus $\mathrm{O}_{3}$ in the eight data bins. Correlation coefficients for all bins without regression lines plotted (and more than three sample pairs) were $\leq 0.34$.

regions are most prominent below $6 \mathrm{~km}$, with mean concentrations near Asia 2 - 6 times higher. Talbot et al. [this issue (b)] discuss the complete (4 - 8 min sampling resolution) soluble acidic gas data set and suggest that enhancements in Asian air masses reflect combustion and other industrial emissions.

In the same $0-9 \mathrm{~km}$ altitude range where enhanced concentrations of soluble ionic species indicate the influence of sources on the Asian continent, the mean $\mathrm{O}_{3}$ concentrations differ by less than $30 \%$ between regions in any of the altitude bins (Table 1, Figure 2 ). Ozone and ${ }^{210} \mathrm{~Pb}$ concentrations are correlated $(r \geq 0.67)$ in all altitude bins in the remote region (but not near Asia) (Figure 4). This relationship was present in both regions during PEM-West $\mathrm{A}$ (stronger near Asia), and was attributed to pumping of Rn and $\mathrm{O}_{3}$ (and/or $\mathrm{O}_{3}$ precursors) from the continental boundary layer high into the troposphere by deep wet convective systems [Dibb et al., 1996]. The very low concentrations of soluble aerosol-associated species (readily scavenged) and the constant mean concentrations of soluble acidic gases throughout the depth of the free troposphere (reflecting vigorous vertical mixing) over the remote Pacific during PEM-West B would be consistent with deep wet convection over Southeast Asia and Indonesia, providing modified continental air to the remote free troposphere sampled by the DC-8 [Talbot et al., this issue (a), (b)].

It has been suggested that deep wet convective pumping could 

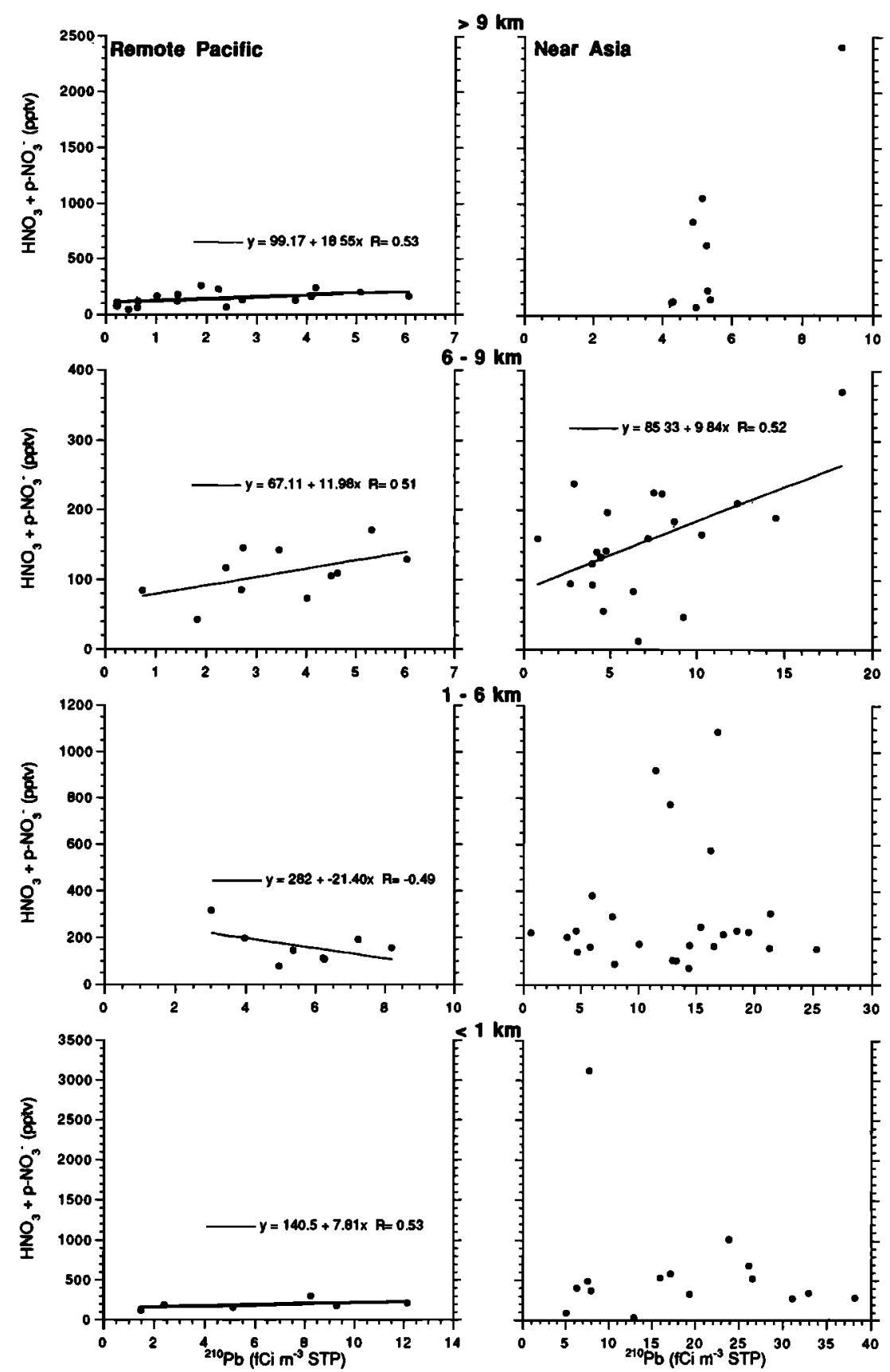

Figure 5. Scatterplots of ${ }^{210} \mathrm{~Pb}$ versus $\mathrm{HNO}_{3}$ plus $\mathrm{p}-\mathrm{NO}_{3}{ }^{-}$in the eight data bins. Correlation coefficients for all bins without regression lines plotted (and more than three sample pairs) were $\leq 0.30$.

also explain the correlation often observed between ${ }^{210} \mathrm{~Pb}$ and inorganic nitrate at sampling sites on Pacific Islands, since both the ${ }^{222} \mathrm{Rn}$ and $\mathrm{NO}_{x}$ precursors are only sparingly soluble [e.g., Savoie et al., 1989; Balkanski et al., 1993]. No relationship was found between ${ }^{210} \mathrm{~Pb}$ and $\mathrm{p}-\mathrm{NO}_{3}{ }^{-}, \mathrm{HNO}_{3}$, or their sum during PEM-West $\mathrm{A}$, though a persistent correlation was seen between ${ }^{210} \mathrm{~Pb}$ and peroxyacetylnitrate (PAN) [Dibb et al., 1996]. Our PEM-West B samples also fail to reveal any strong relationship between ${ }^{210} \mathrm{~Pb}$ and either of the two main inorganic nitrate species (not shown) or their sum (Figure 5). Likewise, no relationships were found between ${ }^{210} \mathrm{~Pb}$ and $\mathrm{NO}$ (no $\mathrm{NO}_{2}$ measurements were made during PEM-West B). However, relatively high correlations were found between ${ }^{210} \mathrm{~Pb}$ and PAN in all free tropospheric bins over the remote Pacific, with a weaker relationship found only in the $6-9 \mathrm{~km}$ range closer to Asia (Figure 6). We hypothesize that these ${ }^{210} \mathrm{~Pb}-\mathrm{PAN}$ relationships during PEM-West $B$ are again reflecting the importance of deep wet convection on the composition of the troposphere over the western Pacific, though the convective activity in spring is more equatorial than during fall, when the storms were mainly over central Asia. Meteorological analyses [Merrill et al., this issue], the large-scale characterization of air masses from the UV-differential absorption lidar (DIAL) records (E.V. Browell et al., unpublished manuscript, 1997), and the distributions of hydrocarbons and halocarbons [Blake et al., this issue] for PEM-West B also lead to the conclusion that deep convective pumping played a major role in the more southern and eastern regions of the western Pacific sampled by the 

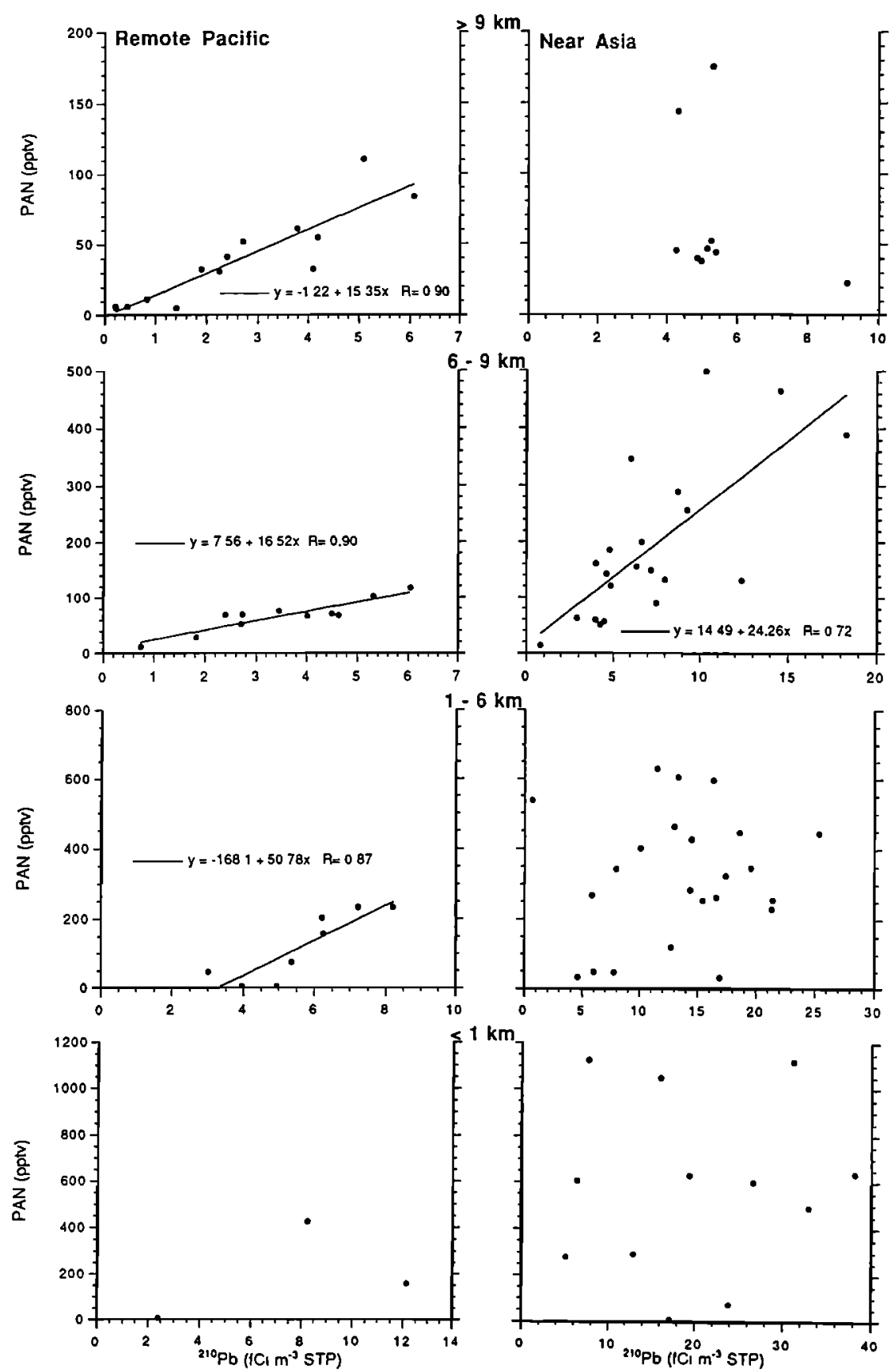

Figure 6. Scatterplots of ${ }^{210} \mathrm{~Pb}$ versus PAN in the eight data bins. Correlation coefficients for all bins without regression lines plotted (and more than three sample pairs) were $\leq 0.32$.

DC-8. Also, these other analyses suggest that the air masses encountered near Asia at $6-9 \mathrm{~km}$ were significantly impacted by northward advection of tropical air that had passed through deep clouds in the Intertropical Convergence Zone (ITCZ), with much of the convective activity near the numerous islands of Indonesia. This bin is the only one near Asia that showed a correlation between ${ }^{210} \mathrm{~Pb}$ and PAN (Figure 6).

We speculated that this relationship between ${ }^{210} \mathrm{~Pb}$ and PAN, relatively near the presumed continental source, may account for the correlation between ${ }^{210} \mathrm{~Pb}$ and inorganic nitrate observed further downwind through thermal decomposition of PAN to $\mathrm{NO}_{x}$ and subsequent formation of $\mathrm{HNO}_{3}$ and/or p- $\mathrm{NO}_{3}^{-}$[Dibb et al., 1996].
These new data from PEM-West $B$ indicate that the association between ${ }^{210} \mathrm{~Pb}$ and $\mathrm{PAN}$ also occurs during late-winter/early-spring in regions further from Asia. The ratio of $\mathrm{NO}_{3}^{-}{ }^{-10} \mathrm{~Pb}$ over the remote Pacific during PEM-West $\mathrm{B}\left(15-50 \mathrm{pptv} /\left(\mathrm{fCi} \mathrm{m}^{-3}\right)\right.$ ) (Figure 6) is directly comparable to the $\mathrm{NO}_{3}^{-210} \mathrm{~Pb}$ ratio of 27 reported for Samoa [Savoie et al., 1989], though this southern hemisphere site is felt to be receiving long-range continental influence from South America. We can also estimate the $\mathrm{NO}_{3}{ }^{-}{ }^{10} \mathrm{~Pb}$ ratio at Enewetak during spring as being approximately 20, from Sea-Air Exchange (SEAREX) data reported for $1979\left({ }^{210} \mathrm{~Pb}\right.$ [Turekian and Cochran, 1981]) and 1981-1982 $\left(\mathrm{NO}_{3}^{-}\right.$[Prospero et al., 1985]). These observations suggest that a large fraction of the nitrate reaching 

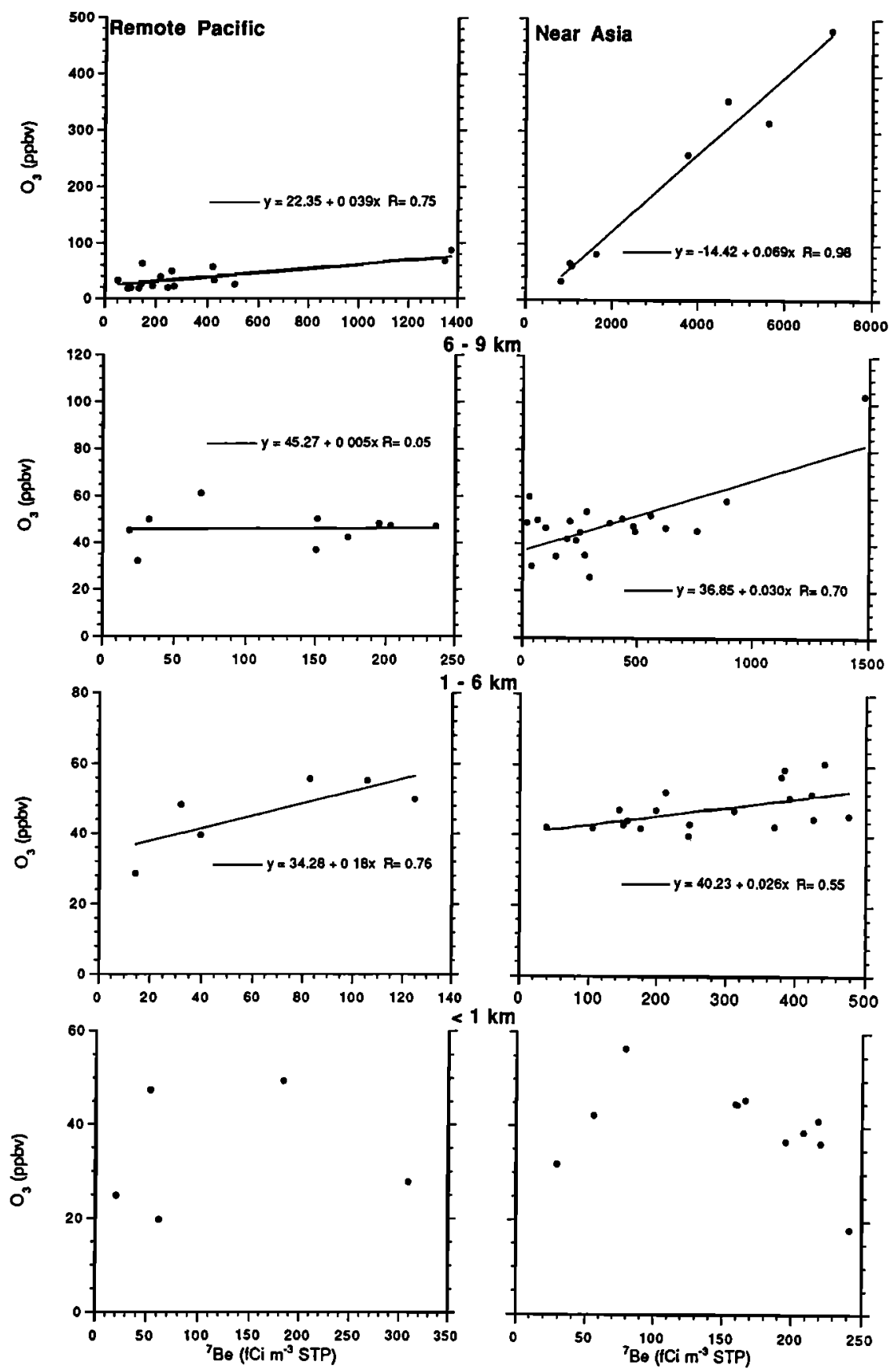

Figure 7. Scatterplots of ${ }^{7} \mathrm{Be}$ versus $\mathrm{O}_{3}$ in the eight data bins. Correlation coefficients for all bins without regression lines plotted (and more than three sample pairs) were $\leq 0.20$.

remote Pacific islands could originate as PAN (or insoluble precursors of PAN) which are then injected into the upper troposphere, along with high concentrations of ${ }^{222} \mathrm{Rn}$, by convective pumping. It should be pointed out that the $\mathrm{NO}_{3}{ }^{-} /{ }^{10} \mathrm{~Pb}$ ratio at the tropical North Atlantic Atmosphere/Ocean Chemistry Experiment (AEROCE) site on Barbados is also quite constant through the year at about 17 , and very similar to those over the remote Pacific, despite much higher concentrations of both species [Savoie et al., 1992]. At Barbados it is clear that the $\mathrm{NO}_{3}^{-}-{ }^{210} \mathrm{~Pb}$ relationship is reflecting transport from continental sources, but the possible role of PAN as an intermediary has not yet been investigated.

Stratospheric Influence. The concentrations of ${ }^{7} \mathrm{Be}, \mathrm{O}_{3}$, and
$\mathrm{HNO}_{3}$ are all strongly enhanced in the $>9 \mathrm{~km}$ altitude bin near Asia (Figure 2, Table 1). Concentrations of $\mathrm{SO}_{4}{ }^{2}$ also increase in this bin, though by a relatively smaller amount. The very high concentrations of ${ }^{7} \mathrm{Be}$ and $\mathrm{O}_{3}$ in some of the samples (Figure 1) are clear evidence of stratospheric inputs into the air masses sampled [e.g., Dutkiewicz and Husain, 1979, 1985]. Stratosphere to troposphere exchange has long been known to reach its annual peak in spring at midlatitudes [e.g., Staley, 1982; Dutkiewicz and Husain, 1985], so evidence of stratospheric influence on the composition of the troposphere was expected during PEM-West $\mathrm{B}$. However, ${ }^{7} \mathrm{Be}-\mathrm{O}_{3}$ relationships in the eight region/altitude bins suggest that any stratospheric influence was quite weak outside of the highest near 
PEM-WEST B FLIGHT ROUTE

MISSION 17, FROM 010 TO 7 9, MARCH 11,1994

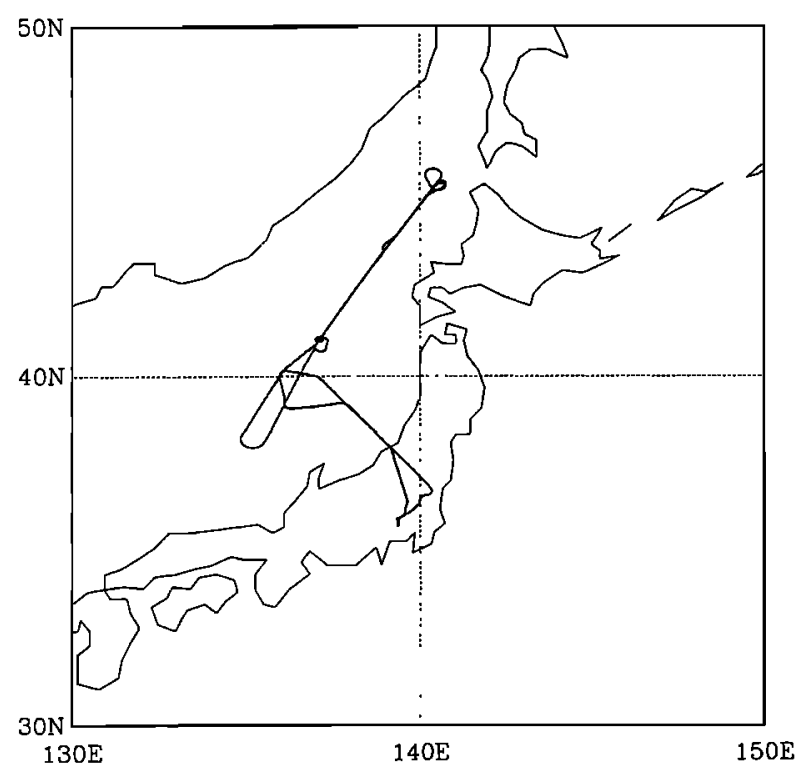

Figure 8. Flight track for flight 17, 0010-0709, March 11, 1994, over the Sea of Japan. The vertical wall was flown along the south west to north east trending "line" between about $38^{\circ} \mathrm{N}$ and $45^{\circ} \mathrm{N}$.

Asia bin (Figure 7). In fact, all of the samples with $\mathrm{O}_{3}$ concentrations $>110$ ppbv and ${ }^{7} \mathrm{Be}>1.7 \mathrm{pCi} \mathrm{m}^{-3}$ were collected on a single flight.

This particular flight (17) provided a unique opportunity to characterize stratosphere to troposphere exchange through a tropopause fold [e.g., Danielsen, 1968, 1980; Danielsen and Mohnen, 1977; Danielsen et al., 1987]. The flight track included long constant-altitude legs at five levels along a SW-NE line over the Sea of Japan (Figure 8). The highest altitude leg $(10.7 \mathrm{~km})$ was flown twice, first from SW to NE, and then back. Aerosol and $\mathrm{O}_{3}$ vertical profiles measured with the UV-DIAL instrument on the 3.4 $\mathrm{km} \mathrm{leg}$ of the wall clearly captured the structure of the fold the plane had flown through earlier (Plate 1). Concentrations of the stratospheric tracers ${ }^{7} \mathrm{Be}$ and $\mathrm{O}_{3}$ are significantly higher on the southern half of both $10.7 \mathrm{~km}$ legs, decreasing to the north of the fold axis (Figure 9). These results are consistent with the dynamic mixing around the jet causing the tropopause fold, as such mixing has been described by Danielsen and coworkers.

Kritz et al. [1991] reported $\mathrm{O}_{3}$ and ${ }^{7} \mathrm{Be}$ measurements through a similar tropopause fold near $35^{\circ} \mathrm{N}$ over the southwestern United States as part of the Stratosphere-Troposphere Exchange Project (STEP) program. In this earlier study, measurements were made in the stratosphere (12.5 $-20.7 \mathrm{~km})$, and peak concentrations reached $13.5 \mathrm{pCi} \mathrm{m}^{-3} \mathrm{STP}^{7} \mathrm{Be}$ and $3.8 \mathrm{ppmv} \mathrm{O}_{3}$. However, eight samples collected between 12.5 and $15.2 \mathrm{~km}$ ranged $3.1-7.7 \mathrm{pCi}^{7} \mathrm{Be} \mathrm{m}^{-3}$ STP and 193 - 537 ppbv $\mathrm{O}_{3}$, values that are comparable to our measurements at $10.7 \mathrm{~km}$ (Figures 7 and 9). Regression analysis indicates very similar relationships, with $1 \mathrm{pCi}^{7} \mathrm{Be} \mathrm{m}^{-3} \mathrm{STP}$ associated with $59 \mathrm{ppbv} \mathrm{O}_{3}$ at the lower levels we sampled, while the slope found in the subset of the STEP data set was $67 \mathrm{ppbv} /(\mathrm{pCi}$ $\mathrm{m}^{-3}$ STP). Kritz et al. [1991] observed a further steepening of slope between their lowest sampling altitudes and $20 \mathrm{~km}$.

The fraction of stratospheric air in the samples we collected at $10.7 \mathrm{~km}$ can be roughly estimated from the ${ }^{7} \mathrm{Be}$ concentrations. If we assume equilibrium ${ }^{7} \mathrm{Be}$ concentrations at $40^{\circ} \mathrm{N}$ of about $8 \mathrm{pCi}$ $\mathrm{m}^{-3} \mathrm{STP}$ at $15 \mathrm{~km}$, or $12 \mathrm{pCi} \mathrm{m}^{-3}$ STP at $20 \mathrm{~km}$ [Bhandari et al., 1966], and take $0.5 \mathrm{pCi} \mathrm{m}^{-3} \mathrm{STP}$ as a good estimate of the concentration at the top of the troposphere [Kritz et al., 1991 and references therein], we calculate that a $43-88 \%$ contribution of $15 \mathrm{~km}$ stratospheric air could account for the measured ${ }^{7} \mathrm{Be}$. If the stratospheric air originated as high as $20 \mathrm{~km}$, the fraction required would drop to $22-45 \%$ for the $3.8-7.1 \mathrm{pCi}^{7} \mathrm{Be} \mathrm{m}^{-3} \mathrm{STP}$ in these 4 samples. It should be noted that ${ }^{7} \mathrm{Be}$ data from the stratosphere to confirm the assumption of equilibrium are relatively sparse and that the dynamic processes associated with mixing around tropopause folds can be quite complex, potentially making simple linear mixing calculations suspect. However, Kritz et al. [1991] found good agreement for 3 different tracers with this approach, in a dynamically more complex fold than the lidar image (Plate 1) indicates we encountered, suggesting that the ${ }^{7} \mathrm{Be}$ observations should provide reasonable constraints on stratospheric influence in this case.

As a test of the validity of the assumed ${ }^{7} \mathrm{Be}$ end members and validity of the linear mixing assumption, we can use the calculated fractions of stratospheric air to estimate concentrations of other stratospheric tracers in the presumed stratospheric source. The mean $\mathrm{O}_{3}$ mixing ratio in the highest altitude bin near Asia was $187 \mathrm{ppbv}$ (Table 1), but this drops to $55 \mathrm{ppbv}$ if the four samples from flight 17 are excluded. Using $55 \mathrm{ppbv} \mathrm{O}_{3}$ as the tropospheric end-member yields estimated concentrations of $440-600 \mathrm{ppbv}$ if the stratospheric air is assumed to have come from $15 \mathrm{~km}$, or $640-883$ if the source of the stratospheric air was at $20 \mathrm{~km}$. The levels estimated for the $15 \mathrm{~km}$ source are consistent with $\mathrm{O}_{3}$ profiles from sondes in April 1989 [Austin and Midgley, 1994], while measured levels at 20 km were three- to four-fold higher than our estimates. The suggestion of a lower stratospheric origin for the air transferred into the troposphere through the fold is in accord with the dynamics of this mixing process [e.g., Danielsen, 1968, 1980; Danielsen and Mohnen, 1977; Danielsen et al., 1987].

The similar pattern of $\mathrm{HNO}_{3}$ concentrations indicates a strong stratospheric source for this species as well. As was the case for $\mathrm{O}_{3}$, excluding the four samples from flight 17 reduces the mean $\mathrm{HNO}_{3}$ concentration above $9 \mathrm{~km}$ near Asia considerably, from 615 to 122 pptv. This estimate for an upper tropospheric end-member and the ${ }^{7}$ Be-based estimates of stratospheric fraction yield estimated $\mathrm{HNO}_{3}$ concentrations at $15 \mathrm{~km}$ in the lower stratosphere from 1.9 to 4.1 ppbv, in harmony with our measurements and model results that predict $\mathrm{HNO}_{3}$ should be the dominant reactive $\mathrm{N}$ species in the lower stratosphere. Talbot et al. [this issue (b)] discuss the relationships between $\mathrm{HNO}_{3}$, other measured reactive $\mathrm{N}$ species, $\mathrm{O}_{3}$ and $\mathrm{N}_{2} \mathrm{O}$ observed over the Sea of Japan and in several other less extensive encounters with stratospherically impacted air during PEM-West B and compare them to the limited number of previous in situ measurements of this suite of species in stratospheric air.

The concentrations of ${ }^{210} \mathrm{~Pb}$ in the four samples from this flight averaged $6.1 \mathrm{fCi} \mathrm{m}^{-3} \mathrm{STP}$, slightly higher than the overall mean for all samples in this bin (Table 1). Similar calculations suggest that concentrations in the lower stratosphere are in the range of 5.3 - 9.7 fCi ${ }^{210} \mathrm{~Pb} \mathrm{~m}^{-3} \mathrm{STP}$. These concentrations would be in very good agreement with the mean of $8 \mathrm{fCi} \mathrm{m}^{-3} \mathrm{STP}$ for the $15-19 \mathrm{~km}$ range (Krey as cited by Lambert et al., [1982]), but the small difference between the assumed tropospheric end-member and estimated stratospheric end-member suggests that the latter may be quite uncertain.

Comparisons Between Spring and Fall Seasons. The spring timing of PEM-West B was selected to allow sampling of air 


\section{SIBERIA OUTFLOW \\ PEM WEST-B \\ FLIGHT 17}

11 MAR 94

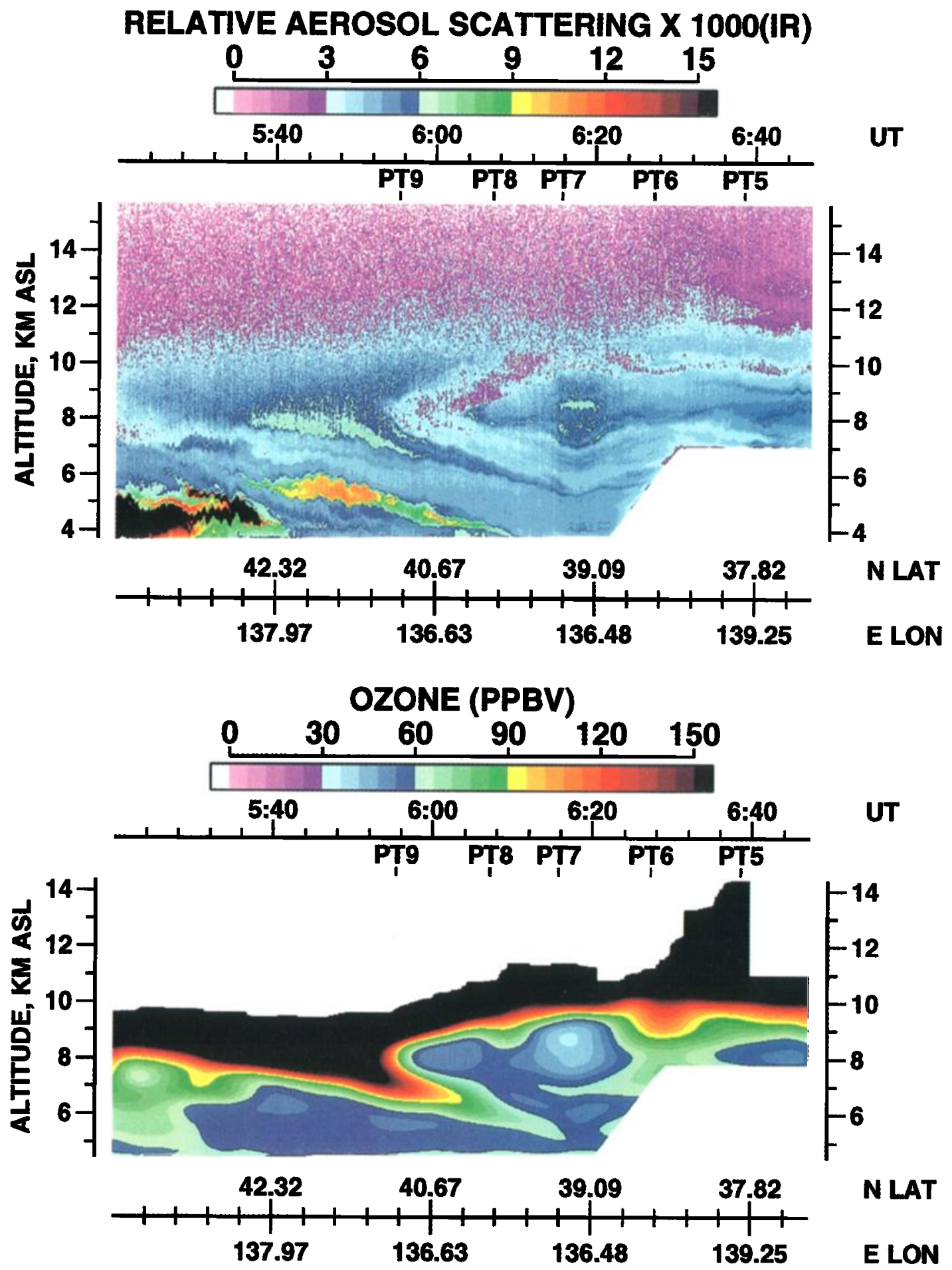

Plate 1. Zenith profiles of $\mathrm{O}_{3}$ and aerosol scattering from the UV-DIAL instrument. These data were collected during the $3.4 \mathrm{~km}$ leg of the vertical wall, looking upward at the air masses the DC-8 had earlier flown through. A tropopause fold is clearly outlined in both sets of data. 

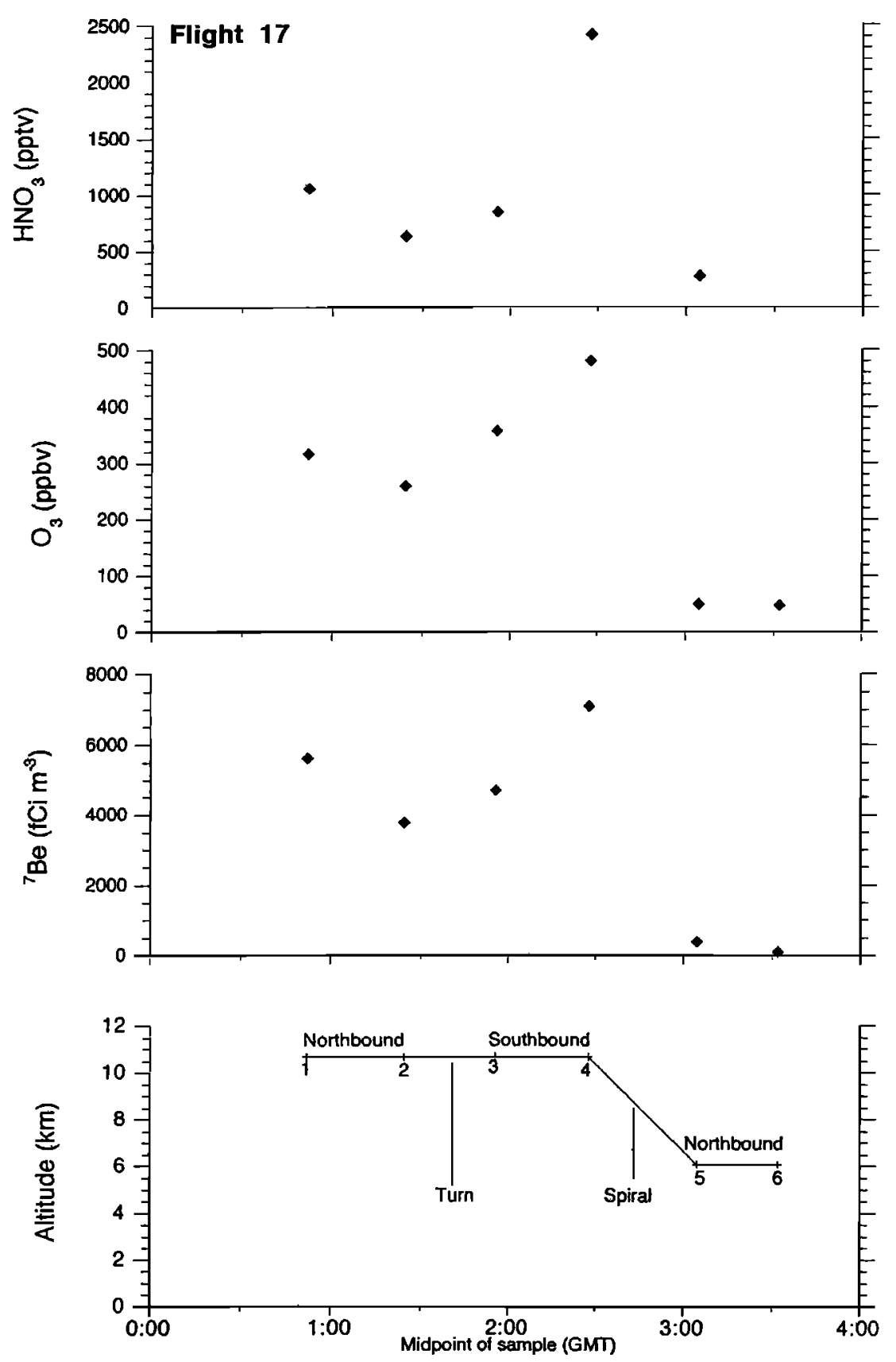

Figure 9. Mean concentrations of $\mathrm{HNO}_{3}, \mathrm{O}_{3}$ and ${ }^{7} \mathrm{Be}$ in the first six aerosol sampling intervals of flight 17. As depicted in the lower panel, the first four aerosol samples were all collected during the $10.7 \mathrm{~km}$ leg of the wall, with five and six from the $6.1 \mathrm{~km} \mathrm{leg.}$

masses over the Pacific during the period of peak Asian dust outflow [e.g., Prospero et al., 1985; Merrill et al., 1989; Gao et al., 1992]. Comparisons to PEM-West A results (conducted in the fall) should reflect the expected seasonal contrast. We noted that most soluble aerosol-associated species were not detected above the boundary layer during PEM-West A [Dibb et al., 1996]; thus there was general enhancement of these species during PEM-West B (Table 1).

The largest difference in the binned data for aerosol-associated species and $\mathrm{O}_{3}$ near Asia reflects the intrusion of stratospheric air into the upper troposphere (discussed in the preceding section) (Figure 10). Enhancements of ${ }^{210} \mathrm{~Pb}, \mathrm{NO}_{3}{ }^{-}, \mathrm{SO}_{4}{ }^{=}$, and $\mathrm{NH}_{4}{ }^{+}$are apparent throughout the tropospheric column near Asia in spring, but they do not exceed a factor of 3. Over the remote Pacific, ${ }^{210} \mathrm{~Pb}$ and $\mathrm{O}_{3}$ are the only species to show large concentration differences between the seasons, with the $1-9 \mathrm{~km}$ region containing at least twice as much of both species during spring (Figure 11). Given the previously noted widespread influence of Asian dust throughout the Pacific during the spring, larger enhancements between PEM-West $A$ and $B$ might have been expected.

These observations may be partially explained by the fact that there was a considerable Asian influence on tropospheric composition over the western Pacific even in the fall season sampled in PEM-West A [e.g., Dibb et al., 1996; Talbot et al., 1996]. Talbot 

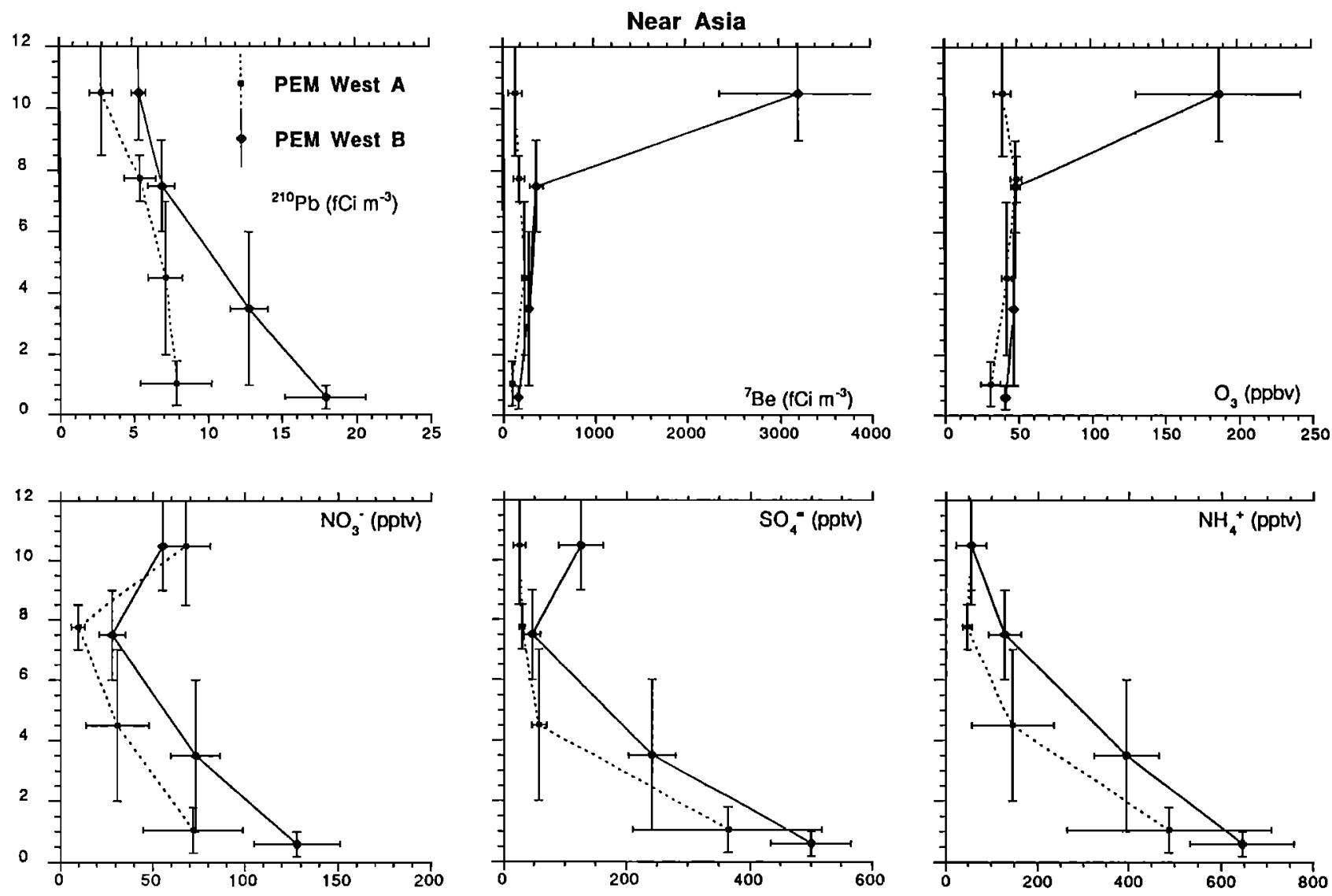

Figure 10. Comparisons between the mean concentrations of selected aerosol-associated species and $\mathrm{O}_{3}$ in four altitude bins near Asia during PEM-West A and PEM-West B.

et al. [this issue (a)] and Blake et al. [this issue] point out that concentrations of sparingly soluble tracers with continental sources (e.g., CO and several nonmethane hydrocarbons (NMHC)) show more pervasive enhancements, up to higher altitudes, over much of the region sampled in PEM-West B than are apparent in easily scavenged constituents like aerosols or the acidic gases. These observations suggest that wet convective pumping of material from the continental boundary layer into the free troposphere may be an important step for transport of Asian signatures over the Pacific during spring, as we have hypothesized for fall [Dibb et al., 1996]. It is also possible that the February-March timing of PEM-West B was too early to capture the peak episodes of dust (and other readily scavenged species) transport from Asia eastward over the Pacific.

\section{Conclusions}

Comparison of the concentrations of aerosol-associated species measured during PEM-West $B$ and A confirmed the expectation that Asian outflow should be stronger in spring than fall, though the enhancement in binned concentrations of the most abundant continentally derived species did not exceed a factor of 3 . The largest enhancements in concentrations of aerosol-associated species were restricted to low $(<6 \mathrm{~km})$ altitudes. In contrast, Talbot et al. [this issue (a)] demonstrate that a strong springtime increase of Asian influence is evident through much of the troposphere if gas phase tracers of combustion and industrial emissions that are less easily scavenged are considered.
Correlations between the concentrations of ${ }^{210} \mathrm{~Pb}$ and $\mathrm{O}_{3}$ in the region sampled on flights out of Guam, where concentrations of anthropogenic aerosols and their soluble gaseous precursors were quite low, reflect the role wet convective pumping of continentalboundary-layer air to the free troposphere plays in the export of pollutants to remote regions. Similar correlations during PEM-West A were limited to the near-Asia region, reflecting a seasonal shift in the occurrence of deep, wet convection from central Asia in summer and fall to Southeast Asia and Indonesia in spring. In the same remote Pacific region, ${ }^{210} \mathrm{~Pb}$ concentrations were also correlated with PAN mixing ratios. During PEM-West $A,{ }^{210} \mathrm{~Pb}-\mathrm{PAN}$ correlations were seen mainly in the near-Asia region. The wet convective pumping mechanism appears to result in free tropospheric air masses which favor the production of PAN over inorganic nitrates, at least during the first few days of transport eastward from the Asian continent that we were able to characterize during the two PEM-West missions. Subsequent decomposition of PAN when these air masses subside over the central Pacific could provide significant amounts of $\mathrm{NO}_{x}$ and allow production of the inorganic nitrates in ${ }^{210} \mathrm{~Pb}$-rich air far from the continental sources.

The distribution of ${ }^{7} \mathrm{Be}$, and its relationship to $\mathrm{O}_{3}$, suggests that stratospheric influence on the composition of the troposphere over the western Pacific was relatively weak, with strongest impacts restricted to the highest latitudes sampled. However, one flight provided the opportunity to sample below and through a welldefined tropopause fold near $40^{\circ} \mathrm{N}$. The peak ${ }^{7} \mathrm{Be}$ concentration measured in the center of the fold at $10.7 \mathrm{~km}\left(7 \mathrm{pCi} \mathrm{m}^{-3}\right)$ was 


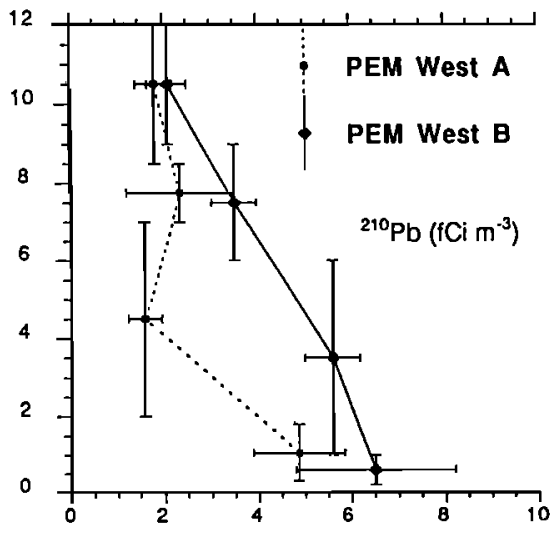

Remote Pacific
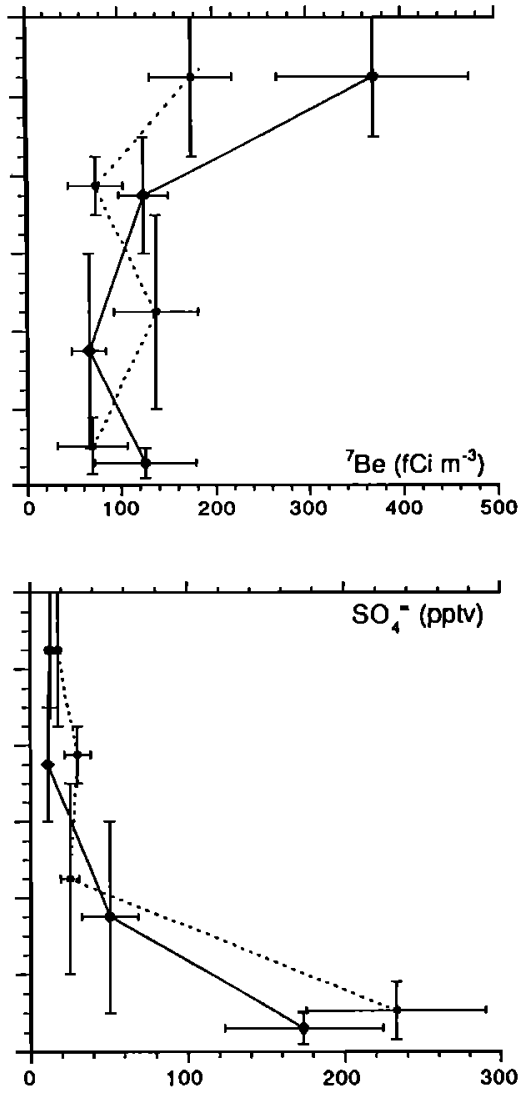
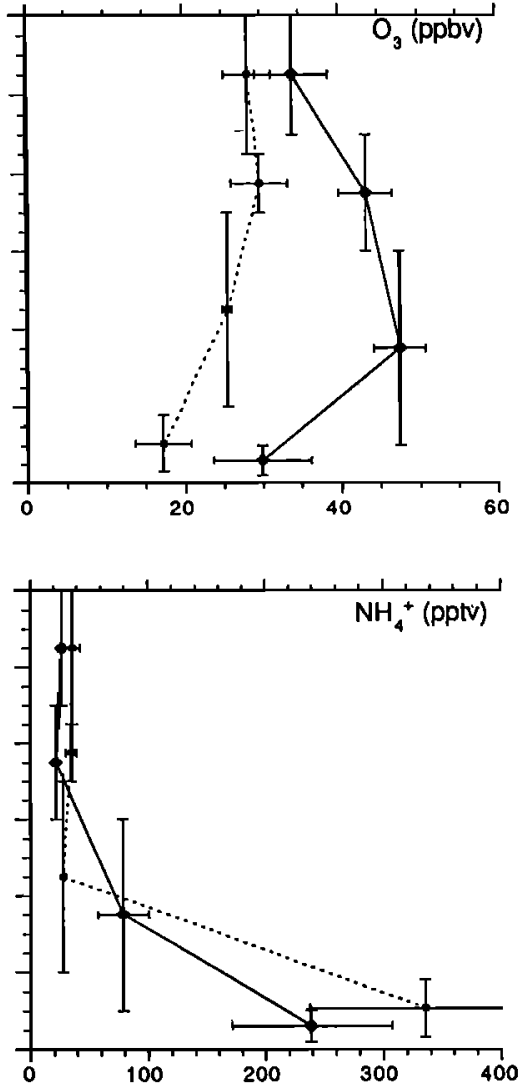

Figure 11. Comparisons between the mean concentrations of selected aerosol-associated species and $\mathrm{O}_{3}$ in four altitude bins over the "remote" Pacific during PEM-West A and PEM-West B.

consistent with a two-component mixture of stratospheric air from $15 \mathrm{~km}(88 \%)$ and upper tropospheric air (12\%). Three other samples collected in and near the fold at the same latitude required greater than $43 \%$ contributions from the same stratospheric source to account for their elevated ${ }^{7} \mathrm{Be}$ concentrations. The next highest ${ }^{7} \mathrm{Be}$ concentration measured on all other PEM-West B flights was only $1.6 \mathrm{pCi} \mathrm{m}^{-3}$, or nearly 2.5 times lower than the lowest concentration measured near the fold, implying a maximum stratospheric fraction well below $20 \%$ in the upper troposphere air masses that were sampled over the western Pacific in February - March 1994.

Acknowledgements. We would like to thank the NASA Ames DC-8 flight and ground crews for their excellent support throughout PEM-West B. Also, the efforts of S. I. Whitlow to ensure that the radionuclide aerosol samples were promptly processed while we were still on deployment are much appreciated. The comments of W. Graustein and an anonymous reviewer improved this paper, and we thank them for their time. This research was supported by the NASA Global Tropospheric Chemistry program.

\section{References}

Austin, J. F., and R. P. Midgley, The climatology of the jet stream and stratospheric intrusions of ozone over Japan, Atmos. Environ., 28, 39$52,1994$.

Balkanski, Y. J., D. J. Jacob, G. M. Gardner, W. C. Graustein, and K. K Turekian, Transport and residence times of tropospheric aerosols inferred from a global three-dimensional simulation of ${ }^{210} \mathrm{~Pb}, J$. Geophys. Res., 98, 20,573-20,586, 1993.
Bhandari, N., D. Lal, and Rama, Stratospheric circulation studies based on natural and artificial radioactive tracer elements, Tellus, 18, 391-405, 1966.

Blake, N. J., D. R. Blake, T.-Y. Chen, J. E. Collins Jr., G. W. Sachse, B. E. Anderson, and F. S. Rowland, Distribution and seasonality of selected hydrocarbons and halocarbons over the western Pacific basin during PEM-West A and PEM-West B, J. Geophys. Res., this issue.

Danielsen, E. F., Stratospheric-tropospheric exchange based on radioactivity, ozone and potential vorticity, J. Atmos.Sci., 25 502-518, 1968.

Danielsen, E. F., Stratospheric source for unexpectedly large values of ozone measured over the Pacific Ocean during Gametag, August 1977, J. Geophys. Res., 85, 401-412, 1980.

Danielsen, E. F., and V. A. Mohnen, Project Duststorm report: Ozone transport, in situ measurements, and meteorological analyses of tropopause folding, J. Geophys. Res., 82, 5867-5877, 1977.

Danielsen, E. F., R. S. Hipskind, S. E. Gaines, G. W. Sachse, G. L. Gregory, and G. F. Hill, Three-dimensional analysis of potential vorticity associated with tropopause folds and observed variation of ozone and carbon monoxide, J. Geophys. Res., 92, 2103-2111, 1987.

Dibb, J. E., R. W. Talbot, K. I. Klemm, G. L. Gregory, H. B. Singh, J. D. Bradshaw, and S. T. Sandholm, Asian influence over the western North Pacific during the fall season: Inferences from lead 210 , soluble ionic species, and ozone, J. Geophys. Res., 101, 1779-1792, 1996.

Dutkiewicz, V. A., and L. Husain, Determination of stratospheric ozone at ground level using ${ }^{~} \mathrm{Be} / \mathrm{ozone}$ ratios, Geophys. Res. Lett., 6, 171-174, 1979.

Dutkiewicz, V. A., and L. Husain, Stratospheric and tropospheric components of Be in surface air, J. Geophys. Res., 90, 5783-5788, 1985.

Hoell, J. M., D. D. Davis, S. C. Liu, R. Newell, H. Akimoto, R. J. McNeal, and R. J. Bendura, The Pacific Exploratory Mission-West, Phase B: February-March, 1994, J. Geophys. Res., this issue.

Kritz, M. A., S. W. Rosner, E. F. Danielsen and H. B. Selkirk, Air mass origins and troposphere-to-stratosphere exchange associated with 
midlatitude cyclogenesis and tropopause folding inferred from ${ }^{7} \mathrm{Be}$ measurements, J. Geophys. Res., 96, 17,405-17,414, 1991.

Lambert, G., G. Polian, J. Sanak, B. Ardouin, A. Buisson, A. Jegou and J. C. Leroulley, Cycle du radon et de ses descendants: Application a l'etude des echanges troposphere-stratosphere, Ann. Geophys., 38, 497 531, 1982.

Merrill, J. T., M. Uematsu, and R. Bleck, Meteorological analysis of longrange transport of mineral aerosols over the North Pacific, J. Geophys. Res., 94, 8584-8598, 1989.

Merrill, J., et al., A Meteorological overview for the Pacific Exploratory Mission-West, Phase B, J. Geophys. Res., this issue.

Prospero, J. M., D. L. Savoie, R. T. Nees, R. A. Duce and J. Merrill, Particulate sulfate and nitrate in the boundary layer over the North Pacific Ocean, J. Geophys. Res., 90, 10,586-10,596, 1985.

Savoie, D. L., J. M. Prospero, J. T. Merrill, and M. Uematsu, Nitrate in the atmospheric boundary layer of the tropical South Pacific: Implications regarding sources and transport, J. Atmos. Chem., 8, 391-415, 1989.

Savoie, D. L., J. M. Prospero, S. J. Oltmans, W. C. Graustein, K. K. Turekian, J. T. Merrill, and H. Levy III, Sources of nitrate and ozone in the marine boundary layer of the tropical North Atlantic, J. Geophys. Res., 97, 11,575-11,589, 1992.

Staley, D. O., Strontium-90 in surface air and the stratosphere: Some interpretations of the 1963-75 data, J. Atmos. Sci., 39, 1571-1590.

Talbot, R. W., et al., Chemical characteristics of continental outflow from Asia to the troposphere over the western Pacific ocean during September-October 1991: Results from PEM-West A, J. Geophys. Res., 10I, 1713-1725, 1996.
Talbot, R. W., et al., Chemical characteristics of continental outflow from Asia to the troposphere over the western Pacific ocean during FebruaryMarch 1994: Results from PEM-West B, J. Geophys. Res., this issue (a).

Talbot, R. W., et al., Large-scale distributions of tropospheric nitric, formic, and acetic acids over the western Pacific basin during wintertime, J. Geophys. Res., this issue (b).

Turekian, K. K., and J. K. Cochran, ${ }^{210} \mathrm{~Pb}$ in surface air at Enewetak and the Asian dust flux to the Pacific, Nature, 292, 522-524, 1981. (Corrigenda, Nature, 294, 670,1981.)

Yamato, M., and H. Tanaka, Aircraft observations of aerosols in the free marine troposphere over the North Pacific Ocean: Particle chemistry in relation to air mass origin, J. Geophys. Res., 99, 5353-5377, 1994.

J. E. Dibb, B. L. Lefer, E. Scheuer, and R. W. Talbot, Institute for the Study of Earth, Oceans, and Space, University of New Hampshire, Durham, NH 03824. (e-mail: jack.dibb@unh.edu)

E. V. Browell and G. L. Gregory, NASA Langley Research Center, Hampton, VA 23681-0001.

J. D. Bradshaw and S. T. Sandholm, Georgia Institute of Technology, Atlanta, GA 30332-0340.

H. B. Singh, NASA Ames Research Center, Moffet Field, CA 94035.

(Received September 6, 1995; revised August 12, 1996; accepted August 20, 1996.) 